\title{
PERLINDUNGAN HUKUM BAGI KONSUMEN DALAM JUAL BELI SECARA ONLINE
}

\author{
Budi Bahreysi \\ Fakultas Hukum Universitas Darmawangsa \\ Jl. KL. Yos Sudarso No. 224 Glugur Kota, Medan - Sumatera Utara \\ Email: tn_zye@yahoo.com
}

\begin{abstract}
Abstrak
Jual beli adalah tindakan hukum terkait dengan pengalihan hak kepemilikan atas barang yang menjadi objek jual beli. Secara umum, kegiatan jual beli tunduk pada ketentuan hukum yang diatur dalam Bab V Kitab Undang-Undang Hukum Perdata (KUHPerdata). Dalam Bab V KUHPerdata diatur tentang pengertian jual beli, batasan jual beli dengan kewajiban penjual dan pembeli dalam transaksi jual beli yang telah dilakukannya. Pada masa ini perkembangan jaman semakin cepat dan kompleks, sangat berpengaruh terhadap kebutuhan setiap manusia. Kemajuan ini ditandai oleh perkembangan di bidang sains dan teknologi yang memudahkan manusia berkomunikasi jarak jauh. Dan untuk konsekuensi ini banyak peristiwa hukum lahir sebagai bentuk perbaikan atas kekurangan yang telah menjadi penghalang bagi semua orang. Jual beli sekarang tidak perlu lagi dilakukan secara tatap muka, tetapi dapat dilakukan dari jarak jauh tanpa harus melihat tanpa mengenal satu sama lain sebelumnya.
\end{abstract}

\section{Kata Kunci: Perlindungan, Konsumen, Jual, Beli, Online}

\section{Abstract}

Buying and selling is a legal act related to the transfer of ownership rights to goods that are objects of sale and purchase. In general, buying and selling activities are subject to the legal provisions stipulated in Chapter V of the Civil Code (Civil Code). In Chapter V of the Civil Code it is regulated about the notion of buying and selling, the limits of buying and selling to the obligation of the seller and the buyer in a sale and purchase transaction that he has done. At this time the development of the era is increasingly fast and complex, very influential on the needs of every human being. This progress was marked by developments in the field of science and technology that made it easier for humans to communicate remotely. And for these consequences many legal events were born as a form of improvement over the shortcomings that had been a barrier for everyone. Buying and selling now no longer need to be done face to face, but can be done remotely without having to see without even knowing each other before.

\section{Keywords: Protection, Consumer, Sell, Buy, Online}

\section{PENDAHULUAN}

Jual beli adalah suatu perbuatan hukum terkait dengan pengalihan hak kepemilikan barang yang menjadi objek jual beli. Secara umum kegiatan jual beli tunduk pada ketentuan hukum yang diatur dalam Bab V Kitab Undang-Undang Hukum Perdata (KUHPerdata). di dalam Bab V KUHPerdata tersebut diatur tentang pengertian jual beli, batasan-batasan jual beli hingga tentang kewajiban penjual dan pembeli dalam suatu transaksi jual beli yang telah dilakukannya. Di dalam Pasal 1457 KUHPerdata diuraikan bahwasannya yang dimaksud jual 
Perlindungan Hukum Bagi...(Budi Bahreysi)

Volume 3 Nomor 2, Juli-Desember 2018, 131-142 DOI: https://doi.org/10.30596/dll.v3i2.3157

beli adalah "suatu persetujuan dengan mana pihak yang satu mengikatkan dirinya untuk menyerahkan suatu barang dan pihak yang lain untuk membayar harga yang dijanjikan".

Sebagai persetujuan untuk dianggap sah maka persetujuan jual beli tersebut wajib memenuhi empat syarat sahnya persetujuan sebagaimana diatur dalam Pasal 1320 KUHPerdata, yakni: (Nm. Wahyu Kuncoro, 2015, h. 8-9)

1. Kesepakatan mereka yang mengikatkan dirinya

2. Kecakapan untuk membuat suatu perikatan

3. Suatu pokok persoalan tertentu

4. Suatu sebab yang tidak terlarang.

Suatu hal yang menarik dalam jual beli adalah secara hukum jual beli sudah dianggap terjadi pada saat penjual and pembeli telah sepakat mengenai barang beserta harga jualnya meskipun barang yang disepakati belum diserahkan oleh penjual kepada pembeli atau pembeli belum membayar harga jual yang disepakati (Nm. Wahyu Kuncoro, 2015, h. 8-9). Hal ini sebagaimana yang diatur di dalam Pasal 1458 KUHPerdata "jual beli dianggap telah terjadi antara kedua belah pihak segera setelah orang-orang itu mencapai kesepakatan tentang barang tersebut beserta harganya, meskipun barang itu belum diserahkan dan harganya belum dibayar.

Berdasarkan penjelasan di atas bahwa dalam jual beli dengan adanya kesepakatan antara penjual dan pembeli maka kedua belah pihak terikat satu sama lain untuk melaksanakan apa yang telah disepakati (asas konsesuil/konsesual) (Nm. Wahyu Kuncoro, 2015, h. 8-9). Berdasarkan ketentuan Pasal 1458 KUHPerdata ini pula "penjual atau pembeli tidak dapat mengingkari pelaksanaan apa yang telah disepakati bersama. Apabila salah satu pihak berupaya untuk mengingkari kesepakatan, pihak yang lain dapat menuntut pihak yang mengingkari tersebut untuk melaksanakan kesepakatan tersebut". (Nm. Wahyu Kuncoro, 2015, h. 8-9).

Pada saat ini perkembangan zaman semakin cepat dan kompleks, sangat berpengaruh terhadap kebutuhan setiap manusia. Kemajuan ini ditandai dengan adanya perkembangan di bidang ilmu pengetahuan dan teknologi yang memudahkan manusia untuk berkomunikasi dari jarak jauh. Dan atas akibat tersebut lahirlah banyak peristiwa hukum sebagai bentuk dari penyempurnaan atas kekurangan-kekurangan yang selama ini menjadi penghambat bagi setiap orang. Jual beli saat ini tidak perlu lagi dilakukan secara tatap muka, namun dapat dilakukan dari jarak jauh tanpa harus melihat bahkan tanpa mengenal satu sama lain sebelumnya.

Lahirnya situs-situs di internet yang menyediakan ruang untuk melakukan kegiatan jual beli menjadi suatu alasan bagi setiap yang tertarik untuk tidak lagi membeli suatu barang dengan harus melihat secara riil atas objek apa yang akan dibelinya. Mulai dari barang elektronik, pakaian, makanan atau pun yang lainnya telah disediakan oleh situs-situs tersebut dengan konsep kenyamanan, aman kepercayaan dan tentu saja dengan biaya murah.

Salah satu situs yang menyediakan ruang untuk melakukan kegiatan jual beli online adalah bukalapak. Di dalam situs https://www.bukalapak.com/ "setiap orang dapat memilih barang-barang yang akan dibeli dengan berbagai jenis bahkan berbagai harga. Masyarakat 
Perlindungan Hukum Bagi...(Budi Bahreysi)

Volume 3 Nomor 2, Juli-Desember 2018, 131-142 DOI: https://doi.org/10.30596/dll.v3i2.3157

sudah sangat dimudahkan untuk memilih barang-barang yang akan dibeli". Di dalam situs tersebut juga dijelaskan "Bukalapak menyediakan tawaran pengembangan online shop. Dijelaskan bahwa pengembangan online shop yang dimaksud adalah menawarkan jual beli online kepada masyarakat yang ingin memiliki online shop sendiri dan ingin memasarkan produknya ke penjuru Indonesia (https://www.bukalapak.com/)". Dengan ini dapat dipahami bahwa bukan Bukalapak saja yang mendagangkan barang-barangnya, namun pihak lain yang sudah terdaftar di Bukalapak juga dapat mendagangkan barang-barangnya.

Adanya Bukalapak sebagai penangung jawab situs penyedia ruang jual beli, namun apakah Bukalapak juga bertanggung jawab atas pelaksanaan jual beli yang dilakukan pembeli dari online shop. Apakah Bukalapak juga bertanggung jawab atas barang dagangan yang dijual oleh online shop. Sebelumnya diketahui bahwa online shop adalah pihak kedua dalam penggunaan situs di situs https://www.bukalapak.com/, namun apakah hubungan hukum atas keduanya (Bukalapak dengan online shop) memiliki kesatuan dalam pertanggung jawaban yang dilakukan oleh Bukalapak sendiri atau dari online shop itu sendiri.

Tidak dapat dipungkiri hal tersebut di atas menjadi permasalahan yang harus diselesaikan untuk melihat sejauh mana pertanggungjawaban dari online shop atas peristiwa hukum yang dibuatnya karena apabila melihat dari sistem yang dimiliki Bukalapak, online shop memiliki kebebasan atas barang-barang yang dijualnya.

Berdasarkan hal tersebut, maka yang menjadi permasalahan dalam penelitian ini adalah bagaimana perlindungan hukum bagi konsumen dalam jual beli secara online? Sehingga nantinya dapat diketahui hal yang terkat dengan perlindungan hukum terhadap konsumen dalam hal jual beli online.

\section{METODE PENELITIAN}

Penulisan ini menggunakan penelitian hukum normatif. Penelitian hukum Normatif atau penelitian hukum kepustakaan adalah metode atau cara yang dipergunakan di dalam penelitan hukum yang dilakukan dengan cara meneliti bahan pustaka yang ada (Soerjono Soekanto, 2014, h. 13-14). Penelitian hukum normatif adalah penelitian yang digunakan untuk mengkaji penerapan kaedah-kaedah atau norma-norma hukum, dikatakan juga analisis yuridis normatif pada hakekatnya menekankan pada metode dedukatif sebagai pegangan utama, yaitu proses berfikir mulai dari pernyataan yang umum menuju peryataan yang khusus (spesifik) dengan menggunakan logika yang dapat diterima (Johny Ibrahim, 2008, h. 282).

Sifat penelitian ini adalah deskriptif analisis. Deskriptif ialah satu kaedah upaya pengolahan data menjadi sesuatu yang dapat diutarakan secara jeals dan tepat dengan tujuan agar dapat dimengerti oleh orang yang tidak langsung mengalaminya sendiri. Analisis adalah suatu usaha untuk mengamati secara detail sesuatu hal atau benda dengan cara menguraikan komponen-komponen pembentuknya atau penyusunnya untuk di kaji lebih lanjut.

Sesuai jenis dan sifat penelitiannya, maka sumber data yang digunakan dalam penulisan ini adalah data skunder yang terdiri dari bahan hukum primer berupa: Kitab Undang-Undang Hukum Pidana; Undang-Undang Nomor 8 Tahun 1999 tentang Perlindungan Konsumen, 
Jurnal Ilmu Hukum

FAKULTAS HUKUM UMSU
Perlindungan Hukum Bagi...(Budi Bahreysi)

Volume 3 Nomor 2, Juli-Desember 2018, 131-142 DOI: https://doi.org/10.30596/dll.v3i2.3157

Undang-Undang Nomor 11 Tahun 2008 tentang Informasi dan Transaksi Elekronik sebagaimana telah diubah oleh Undang-Undang Nomor 19 Tahun 2016 tentang Perubahan Atas Undang-Undang Nomor 11 Tahun 2008 tentang Informasi dan Transaksi Elektronik, Peraturan Pemerintah Nomor 82 Tahun 2012 tentang Penyelenggaraan Sistem dan Transaksi Elektronik.. Bahan hukum sekunder, yang memberikan penjelasan mengenai bahan hukum primer, seperti: undang-undang, buku-buku, sumber Internet, dan lain sebagainya. Bahan hukum tertier, yakni bahan yang memberikan petunjuk maupun penjelasan terhadap bahan hukum primer dan sekunder, seperti: kamus bahasa Indonesia

Teknik pengumpulan data sekunder pada penelitian tesis ini menggunakan studi pustaka yang memiliki arti bahwa data yang diperoleh melalui penelusuran kepustakaan berupa data skunder yang ditabulasi kemudian disistemasikan dengan memilih perangkat-perangkat hukum yang relevan dengan objek penelitian. Keseluruhan data ini kemudian digunakan untuk mendapatkan landasan teoritis berupa bahan hukum positif, pendapat-pendapat atau tulisan para ahli atau pihak lain berupa informasi baik dalam bentuk formal maupun melalui naskah resmi.

\section{PEMBAHASAN}

\section{Perlindungan Hukum Bagi Konsumen Dalam Jual Beli Secara Online}

\section{Jual beli secara online menurut KUHPerdata}

Kemajuan teknologi informasi yang demikian pesat telah menyebabkan perubahan kegiatan kehidupan manusia dalam berbagai bidang yang secara langsung telah memengaruhi lahirnya bentuk-bentuk perbuatan hukum baru. Pemanfaatan jaringan internet sebagai sarana untuk mempermudah aktifitas ternyata memberi manfaat yang cukup besar. Di dalam Undang-Undang Nomor 19 Tahun 2016 yang merupakan perubahan dari Undang-Undang Nomor 11 tahun 2008 tentang Transaksi Elektronik telah diatur bagaimana bentuk suatu perjanjian dengan menggunakan sarana alat elektronik.

Di dalam Undang-Undang Nomor 19 Tahun 2016 tentang Informasi dan Transaksi Elektronik tidak mengenal kata jual beli, namun undang-undang hanya mengenal kata kontrak elektronik yang memiliki pengertian perjanjian. Kontrak elektronik ini pun adalah suatu tindakan aplikatif dari kegiatan transaksi elektronik. Lalu apakah kontrak elektronik dapat dikatakan sebagai perjanjian jual beli?

Perjanjian elektronik atau kontrak elektronik dikenal dengan istilah electronic contract atau E-ontract. Bryan A. Garner (Bryan A. Garner, 2009: 590) memberikan pengertian kontrak elektronik sebagai berikut:

Any type of contract formed in the course of e-commerce by (1) the interaction of two or more individuals using electronic means, such as e-mail, (2) the interaction of an individual with an electronic agent, such as a computer program, or (3) the interaction of at least two electronic agents that are programmed to recognize the existence of a contract. Traditional contract principles and remedies usu. apply to e-contracts. Also termed electronic contract. 
Jurnal Ilmu Hukum

FAKULTAS HUKUM UMSU
Perlindungan Hukum Bagi...(Budi Bahreysi)

Volume 3 Nomor 2, Juli-Desember 2018, 131-142 DOI: https://doi.org/10.30596/dll.v3i2.3157

Thomas J. Smedinghoff (Thomas J. Smedinghoff, 1996, h. 79-80) memberikan pengertian atas kontrak elektronik yaitu "suatu perikatan ataupun hubungan hukum yang dilakukan secara elektronik dengan memadukan jaringan (networking) dari sistem informasi berbasiskan komputer (computer based information system) dengan sistem surat elektronik ( $e$ mail) atau dikombinasi dengan media komunikasi elektronik lainnya". Sedangkan menurut Johannes Gunawan (Johannes Gunawan, 2003, h. 47), kontrak elektronik (digital contract) adalah "kontrak baku yang dirancang, dibuat, ditetapkan, digandakan dan disebarluaskan secara digital melalui situs internet (website) secara sepihak oleh pembuat kontrak (dalam hal ini pelaku usaha) untuk ditutup secara digital) pula oleh penutup kontrak (dalam hal ini konsumen)".

Berdasarkan kejadiannya, kontrak elektronik dapat diklasifikasikan dari beberapa cara, yaitu: (Ridwan Khairandy, 2001, h. 49-50)

1) Kontrak melalui chatting dan video conference

Chatting dan video conferece merupakan alat komunikasi yang disediakan internet yang biasa digunakan untuk dialog interaktif secara langsung, kontrak melalui media ini pada dasarnya sama dengan pembuatan kontrak konvensional hal yang membedakannnya hanyalah pada posisi dan lokasi para pihak yang dihubunginya. Sehingga kesepakatan para pihak terjadi ketika customer dan merchant menyepakati terhadap apa yang diperjanjikan, dengan model ini para pihak mempunyai posisi tawar yang seimbang sehingga dapat merundingkan mengenai isi dari kontrak tersebut. Selain itu dengan model ini khususnya video conference maka dapat dibuktikan apakah para pihak cakap untuk membuat suatu perikatan atau tidak.

2) Kontrak melalui e-mail

Kontrak melaui email dapat berupa kontrak e-mail murni di mana penawaran yang dikirim kepada seseorang atau kepada banyak orang yang tergabung dalam mailing list, penerimaan dan pemberitahuan seluruhnya dikirimkan melalui e-mail. Selain itu, kontrak melalui e-mail dapat berupa gabungan beberapa formula yang ketika penawaran barangnya diberikan di situs web yang mengirimkan penawarannya, dan penerimaannya dikirimkan melalui e-mail. Selain itu kontrak melalui e-mail jika dikaitkan dengan kontrak konvensionl tidak menimbulkan persoalan, karena peraturan yang berkaitan dengan surat dapat diterapkan dalam kontrak melalui $e$ mail. Dengan model ini kesepakatan terjadi ketika seseorang yang menerima e-mail penawaran mengirimkan email balasan bahwa ia menerima penawaran tersebut

3) Kontrak melalui web (situs)

Kontrak memalui web biasanya kompleks, karena melibatkan pihak-pihak di luar yang mengadakan kontrak. Pihak-pihak yang terkait diantaranya adalah pihak-pihak otentifikiasi (penyedia sertifikat digital), lembaga keuangan yang memfasilitasi pembayaran melalui web, pemberi label yang mensertifikasi yang menyatakan bahwa halaman web tersebut adalah aman. Dalam model ini, kesepakatan terjadi ketika customer setuju dengan apa yang disebut user agreement yang berisi mengenai hak dan kewajiban customer, pada saat ia mendaftar sebagai anggota web tersebut

Pasal 1 angka 2 Undang-Undang Nomor 19 Tahun 2016 tentang Informasi dan Transaksi Elektronik menyebutkan bahwa transaksi elektronik adalah perbuatan hukum yang 
Jurnal Ilmu Hukum FAKULTAS HUKUM UMSU
Perlindungan Hukum Bagi...(Budi Bahreysi)

Volume 3 Nomor 2, Juli-Desember 2018, 131-142 DOI: https://doi.org/10.30596/dll.v3i2.3157

dilakukan dengan menggunakan Komputer, jaringan Komputer, dan/atau media elektronik lainnya. Di dalam Undang-Undang Nomor 19 Tahun 2016 tentang Informasi dan Transaksi Elektronik tidak dijelaskan perbuatan hukum apa yang dimaksud, namun apabila memahami arti dari frase perbuatan hukum itu sendiri maka artinya adalah suatu perbuatan yang menimbulkan hak dan kewajiban. Perbuatan hukum ini pun dibedakan menjadi dua jenis (Muhammad Saidi Is, 2015, h. 90):

1) Perbuatan hukum yang bersegi satu adalah setiap perbuatan yang berakibat hukum (rechtsgvlog) dan akibat hukum ditimbulkan oleh kehendak satu subjek hukum yaitu satu pihak saja.

2) Perbuatan hukum yang bersegi dua adalah setiap perbuatan hukum yang akibat hukumnya ditimbulkan oleh kehendak dua subjek, yaitu dua pihak atau lebih. Setiap perbuatan hukum bersegi dua merupakan perjanjian

Bahwa apabila merujuk pada pengertian di atas maka pengertian transaksi elektronik adalah frase kata kerja yang mengarah kepada pengertian suatu kegiatan melakukan perjanjian. Pemahaman ini didasari dengan apa yang ada dalam Pasal 18 Ayat 1 UndangUndang Nomor 19 Tahun 2016 tentang Informasi dan Transaksi Elektronik "Transaksi Elektronik yang dituangkan ke dalam Kontrak Elektronik mengikat para pihak". Dari pengertian tersebut transaksi elektronik adalah suatu bentuk kata kerja yang bersifat umum, apakah bentuk perjanjian jual beli atau perjanjian lainnya tergantung para pihak yang memilih jenis perjanjiannya. Sedangkan kontrak elektronik adalah suatu frase kata benda yang memiliki arti penuangan dari transaksi elektronik tersebut.

Bahwa selanjutnya atas apa yang telah dijelaskan di atas dan kaitannya dengan KUHPerdata adalah Undang-Undang Nomor 19 Tahun 2016 sama sekali tidak memiliki penjelasan lebih lanjut jenis transaksi elektronik apa yang dimaksud. Dan apabila dikaitkan dengan jual beli maka, jual beli adalah suatu perjanjian yang dikenal di dalam KUHPerdata dan pelaksanaan atas perjanjian tersebut sudah diatur di dalam KUHPerdata. Telah dijelaskan sebelumnya, semua perjanjian yang diatur di dalam KUHPerdata melekat Pasal 1320 sebagai syarat sahnya suatu perjanjian. Adapun tambahan syarat sah suatu perjanjian yang diberikan di dalam undang-undang bukan berarti menafikkan apa yang telah diatur di dalam KUHPerdata tersebut. Pada Pasal 47 Peraturan Pemerintah Nomor 82 Tahun 2012 tentang Penyelenggaraan Sistem dan Transaksi Elektronik disebutkan bahwa kontrak elektronik dianggap sah apabila:

1) Terdapat kesepakatan para pihak;

2) Dilakukan oleh subjek hukum yang cakap atau yang berwenang mewakili sesuai dengan ketentuan peraturan perundang-undangan;

3) Terdapat hal tertentu; dan

4) Objek transaksi tidak boleh bertentangan dengan peraturan perundang-undangan, kesusilaan, dan ketertiban umum 
Perlindungan Hukum Bagi...(Budi Bahreysi) DOI: https://doi.org/10.30596/dll.v3i2.3157

Bahwa dari apa yang diatur di dalam Peraturan Pemerintah Nomor 82 Tahun 2012 tentang Penyelenggaraan Sistem dan Transaksi Elektronik tersebut di atas ternyata tidak jauh berbeda dengan apa yang diatur di dalam Pasal 1320 KUHPerdata, yaitu:

1) Kesepakatan mereka yang mengikatkan dirinya

2) Kecakapan untuk membuat suatu perikatan

3) Suatu pokok persoalan tertentu

4) Suatu sebab yang tidak terlarang

Bahwa dengan demikian jual beli online tidak dapat menghilangkan keterkaitannya dengan Pasal 1320 KUHPerdata sebagai bentuk dari syarat sahnya perjanjian dan juga jual beli online tidak dapat menghilangkan Pasal 1457 KUHPerdata sebagai bentuk dari jenis transaksi elektronik tersebut. Bahwa mengingat di dalam KUHPerdata mengenal suatu asas kebebasan berkontrak yang tertuang di dalam Pasal 1338 Ayat 1 yang berbunyi "Semua perjanjian yang dibuat secara sah berlaku sebagai undang-undang bagi mereka yang membuatnya" maka makna dari pasal tersebut adalah (Abdul im Barkatullah dan Teguh Prasetyo, 2006, h. 83):

1) Bebas dalam hal seseorang untuk membuat atau tidak membuat perjanjian

2) Bebas dalam hal subjek, menentukan dengan siapa akan mengikatkan diri dalam perjanjian

3) Bebas dalam hal menentukan bentuk perjanjian

4) Bebas dalamhal menentukan isi dan syarat perjanjian

5) bebas dalam menentukan ketentuan-ketentuan hukum yang berlaku bagi perjanjian yang dibuatnya

Timbulnya hubungan perjanjian jual beli secara online tersebut juga didasari dengan adanya asas kebebasan berkontrak diartikan sebagai suatu asas yang memberikan kebebasan kepada para pihak untuk: (Salim HS, 2006, h. 73)

1) Membuat atau tidak membuat perjanjian

2) Mengadakan perjanjian dengan siapapun

3) Menentukan isi perjanjian, pelaksanaan, dan persyaratannya

4) Menentukan bentuknya perjanjian, yaitu tertulis atau lisan

Apapun perjanjian yang dibuat, baik itu diatur di dalam KUHPerdata atau tidak, suatu perjanjian memiliki beberapa unsur dimana unsur-unsur tersebut termuat ketika suatu perjanjian dibuat. Mariam Darus menerangkan terkait dengan unsur-unsur perjanjian tersebut, yang diantaranya: (Mariam Darus Badrulzaman, 2006, h. 99)

1) Unsur Essensialia

Unsur yang mutlak harus ada. Unsur ini sangat erat berkaitan dengan syarat sahnya perjanjian (Pasal 1320 KUHPerdata) dan untuk mengetahui ada/tidaknya perjanjian serta untuk mengetahui jenis perjanjiannya. Contoh: kesepakatan

2) Unsur naturlia

Unsur yang lazimnya ada/sifat bawaan perjanjian sehingga secara diam-diam melekat pada perjanjian, misalnya menjamin terhadap cacat tersembunyi 
DEIEGA LATA

Jurnal Ilmu Hukum

FAKULTAS HUKUM UMSU
Perlindungan Hukum Bagi...(Budi Bahreysi)

Volume 3 Nomor 2, Juli-Desember 2018, 131-142 DOI: https://doi.org/10.30596/dll.v3i2.3157

\section{3) Unsur accidentalia}

Unsur yang harus tegas diperjanjikan, misalnya pemilihan tempat kedudukan

\section{Perlindungan hukum atas pembeli yang dirugikan online shop}

Bahwa berdasarkan Surat Edaran Menteri Kominfo Nomor 5 Tahun 2016 Tentang Batasan Dan Tanggung Jawab Penyedia Platform Dan Merchant Electronic Commerce, Bukalapak dengan online shop telah dibedakan kedudukannya menjadi suatu istilah masingmasing. Bukalapak disebut sebagai pihak penyedia platform karena Bukalapak adalah pihak yang menyediakan platform itu sendiri. Platform diartikan adalah sebagai wadah berupa aplikasi, situs, internet, dan/atau layanan konten lainnya berbasis internet yang digunakan untuk transaksi dan/atau fasilitas perdagangan melalui sistem elektronik.

Online shop yang telah mendaftar di Bukalapak untuk menjalankan kegiatan perdagangannya disebut dengan istilah pengguna platform. Pengguna platform adalah orang yang mengakses, membuka dan atau melakukan transaksi perdagangan melalui platform yang disediakan oleh penyedia platform. Online shop sebagai pengguna platform menggunakan platform sebagai ruang untuk memperdagangkan barang-barang miliknya. Terkait dengan kerugian yang dialami oleh pembeli apabila timbul suatu kerugian yang dialami oleh pembeli maka secara prinsipnya online shop itulah yang harus bertanggung jawab sebagai pihak pengguna platform, bukan penyedia platform Bukalapak.

Apabila merujuk kepada Pasal 19 Undang-Undang Nomor 8 Tahun 1999 tentang Perlindungan Konsumen dinyatakan:

1) Pelaku usaha bertanggung jawab memberikan ganti rugi atas kerusakan, pencemaran, dan/atau kerugian konsumen akibat mengkonsumsi barang dan/atau jasa yang dihasilkan atau diperdagangkan.

2) Ganti rugi sebagaimana dimaksud pada ayat (1) dapat berupa pengembalian uang atau penggantian barang dan/atau jasa yang sejenis atau setara nilainya, atau perawatan kesehatan dan/atau pemberian santunan yang sesuai dengan ketentuan peraturan perundang-undangan yang berlaku.

3) Pemberian ganti rugi dilaksanakan dalam tenggang waktu 7 (tujuh) hari setelah tanggal transaksi.

4) Pemberian ganti rugi sebagaimana dimaksud pada ayat (1) dan ayat (2) tidak menghapuskan kemungkinan adanya tuntutan pidana berdasarkan pembuktian lebih lanjut mengenai adanya unsur kesalahan.

5) Ketentuan sebagaimana dimaksud pada ayat (1) dan ayat (2) tidak berlaku apabila pelaku usaha dapat membuktikan bahwa kesalahan tersebut merupakan kesalahan konsumen

Bahwa berdasarkan pasal di atas khususnya pada angka 1-5, maka pelaku usahalah yang harus bertanggung jawab apabila pembeli mengalami kerugian atas barang yang telah dibelinya. Kewajiban pelaku usaha untuk mengganti rugi kepada konsumen yang telah mengalami kerugian di saat bersamaan pula menjadi hak bagi konsumen/pembeli mendapatkan ganti rugi tersebut. 
Perlindungan Hukum Bagi...(Budi Bahreysi)

Volume 3 Nomor 2, Juli-Desember 2018, 131-142 DOI: https://doi.org/10.30596/dll.v3i2.3157

Pasal 4 Undang-Undang Nomor 8 Tahun 1999 tentang Perlindungan Konsumen menyatakan hak-hak dan kewajiban yang dimiliki konsumen, antara lain:

1) Hak atas kenyamanan, keamanan, dan keselamatan dalam mengkonsumsi barang dan/atau jasa.

2) Hak untuk memilih barang dan/atau jasa serta mendapatkan barang dan/atau jasa tersebut sesuai dengan nilai tukar dan kondisi serta jaminan yang dijanjikan.

3) Hak atas informasi yang benar, jelas, dan jujur mengenai konsidi dan jaminan barang dan/atau jasa.

4) Hak untuk didengar pendapat dan keluhannya atas barang dan/atau jasa yang digunakan.

5) Hak untuk mendapatkan advokasi, perlindungan, dan upaya penyelesaian sengketa perlindungan konsumen secara patut.

6) Hak untuk mendapat pembinaan dan pendidikan konsumen.

7) Hak untuk diperlakukan atau dilayani secara benar dan jujur serta tidak diskriminatif.

8) Hak untuk mendapatkan kompensasi, ganti rugi dan/atau penggantian, apabila barang dan/atau jasa yang diterima tidak sesuai dengan perjanjian atau tidak sebagaimana mestinya.

9) Hak-hak yang diatur dalam ketentuan peraturan perundang-undangan lainnya.

Bahwa berdasarkan Pasal 4 di atas khususnya pada angka 8 terlihat jelas bahwa konsumen/pembeli memiliki hak untuk mendapatkan kompensasi, ganti rugi, dan atau penggantian apabila barang dan atau jasa yang diterima tidak sesuai dengan perjanjian atau tidak sebagaimana mestinya. Maka dengan demikian sudah jelaslah bahwa online shop adalah sebagai pihak yang harus bertanggung jawab atas kerugian yang dialami oleh pembeli.

Kemudian pada Pasal 8 Ayat 1 huruf f Undang-Undang Nomor 8 Tahun 1999 tentang Perlindungan Konsumen melarang pelaku usaha untuk memperdagangkan barang/jasa yang tidak sesuai dengan janji yang dinyatakan dalam label, etiket, keterangan, iklan atau promosi penjualan barang dan/atau jasa tersebut. Berdasarkan pasal tersebut, ketidaksesuaian spesifikasi barang yang Anda terima dengan barang tertera dalam iklan/foto penawaran barang merupakan bentuk pelanggaran/larangan bagi pelaku usaha dalam memperdagangkan barang.

Apabila pelaku usaha melanggar larangan memperdagangkan barang/jasa yang tidak sesuai dengan janji yang dinyatakan dalam label, etiket, keterangan, iklan atau promosi penjualan barang dan/atau jasa tersebut, maka pelaku usaha dapat dipidana berdasarkan Pasal 62 Ayat 1 Undang-Undang Nomor 8 Tahun 1999 tentang Perlindungan Konsumen yang berbunyi:

Pelaku usaha yang melanggar ketentuan sebagaimana dimaksud dalam Pasal 8, Pasal 9, Pasal 10, Pasal 13 ayat 2, Pasal 15, Pasal 17 ayat 1 huruf a, huruf b, huruf c, huruf e, ayat 2 dan Pasal 18 dipidana dengan pidana penjara paling lama 5 (lima) tahun atau pidana denda paling banyak Rp 2 miliar.

Selanjutnya pada Pasal 49 Ayat 1 Peraturan Pemerintah Nomor 82 Tahun 2012 tentang Penyelenggaraan Sistem dan Transaksi Elektronik menegaskan bahwa pelaku usaha yang menawarkan produk melalui Sistem Elektronik wajib menyediakan informasi yang lengkap 
Perlindungan Hukum Bagi...(Budi Bahreysi)

Volume 3 Nomor 2, Juli-Desember 2018, 131-142 DOI: https://doi.org/10.30596/dll.v3i2.3157

dan benar berkaitan dengan syarat kontrak, produsen, dan produk yang ditawarkan. Lebih lanjut ditegaskan lagi bahwa Pelaku Usaha wajib memberikan kejelasan informasi tentang penawaran kontrak atau iklan. Jika Barang yang dtierima tidak sesuai dengan yang diperjanjikan maka Pasal 49 Ayat 3 Peraturan Pemerintah Nomor 82 Tahun 2012 tentang Penyelenggaraan Sistem dan Transaksi Elektronik mengatur khusus tentang hal tersebut, yakni Pelaku Usaha wajib memberikan batas waktu kepada konsumen untuk mengembalikan barang yang dikirim apabila tidak sesuai dengan perjanjian atau terdapat cacat tersembunyi.

Apabila pelaku usaha menggunakan identitas palsu atau melakukan tipu muslihat dalam jual beli online, maka pelaku usaha dapat dipidana berdasarkan Pasal 378 KUHP tentang penipuan "Barang siapa dengan maksud untuk menguntungkan diri sendiri atau orang lain secara melawan hukum, dengan memakai nama palsu atau martabat palsu, dengan tipu muslihat, ataupun rangkaian kebohongan, menggerakkan orang lain untuk menyerahkan barang sesuatu kepadanya, atau supaya memberi hutang maupun menghapuskan piutang, diancam karena penipuan dengan pidana penjara paling lama empat tahun”.

Pasal 28 Ayat 1 Undang-Undang Nomor 19 Tahun 2016 tentang Informasi dan Transaksi Elektronik, "Setiap Orang dengan sengaja, dan tanpa hak menyebarkan berita bohong dan menyesatkan yang mengakibatkan kerugian konsumen dalam Transaksi Elektronik". Terhadap pelanggaran Pasal 28 Ayat 1 Undang-Undang Nomor 19 Tahun 2016 tentang Informasi dan Transaksi Elektronik tersebut maka dapat diancam pidana sebagaimana diatur dalam Pasal 45A Ayat 1 Undang-Undang Nomor 19 Tahun 2016 tentang Informasi dan Transaksi Elektronik:

Setiap Orang yang dengan sengaja dan tanpa hak menyebarkan berita bohong dan menyesatkan yang mengakibatkan kerugian konsumen dalam Transaksi Elektronik sebagaimana dimaksud dalam Pasal 28 ayat 1 dipidana dengan pidana penjara paling lama 6 (enam) tahun dan/atau denda paling banyak Rp1.000.000.000,00 (satu miliar rupiah).

Namun pertanyaan masih muncul, apakah memang online shop yang harus bertanggung jawab apabila pembeli telah dirugikan? Melihat pertanggung jawaban untuk mengganti rugi sesuai yang ada di dalam Undang-Undang Nomor 8 Tahun 1999 tentang Perlindungan Konsumen maka pelaku usaha lah yang bertanggung jawab. Sedangkan di dalam situs internet atas pelaksanaan jual beli barang di Bukalapak terdapat 2 pelaku usaha, Bukalapak dan Online Shop. Lalu pelaku usaha mana yang harus bertanggung jawab?

Terhadap pertanyaan di atas sebenarnya ada 2 hal yang dapat diperhatikan untuk mengetahui pelaku usaha mana yang harus bertanggung jawab atas kerugian yang dialami pembeli. Yang pertama dilihat dari segi hubungan hukumnya. Pembeli memiliki hubungan hukum dengan penjual. Pembeli membeli barang dari siapa? Dari hubungan hukum akan mudah dilihat pelaku usaha mana yang harus bertanggung jawab atas kerugian yang dialami oleh pembeli.

Pada dasarnya hubungan hukum ini tidak menjadi suatu kebenaran mutlak khususnya pada pihak pembeli. Di dalam Pasal 1 angka 2 Undang-Undang Nomor 8 Tahun 1999 tentang Perlindungan Konsumen khususnya disebutkan konsumen adalah setiap orang pemakai 
Jurnal Ilmu Hukum FAKULTAS HUKUM UMSU
Perlindungan Hukum Bagi...(Budi Bahreysi)

Volume 3 Nomor 2, Juli-Desember 2018, 131-142 DOI: https://doi.org/10.30596/dll.v3i2.3157

barang dan/atau jasa yang tersedia dalam masyarakat, baik bagi kepentingan diri sendiri, keluarga, orang lain, maupun makhluk hidup lain dan tidak untuk diperdagangkan. Pembeli belum tentu menjadi pihak yang memakai barang dan atau jasa, karena bisa saja barang yang dibeli tersebut diberikan kepada pihak lain. Walaupun dengan demikian yang menjadi patokannya adalah bukan pada pembeli semata namun dari mana barang tersebut diperoleh atau dibeli.

Cara yang kedua adalah dengan melihat berdasarkan Surat Edaran Menteri Kominfo Nomor 5 Tahun 2016 Tentang Batasan Dan Tanggung Jawab Penyedia Platform Dan Merchant Electronic Commerce. Bahwa berdasarkan di dalam surat edaran tersebut, Bukalapak selaku penyedia platform sama sekali tidak memiliki kewajiban terkait dengan produk barang yang dijualnya, akan tetapi kewajiban itu ada pada online shop yang mana sebagai pengguna platform yang kedudukannya sebagai pedagang. Huruf D angka 1 huruf a Surat Edaran Menteri Kominfo Nomor 5 Tahun 2016 Tentang Batasan Dan Tanggung Jawab Penyedia Platform Dan Merchant Electronic Commerce disebutkan bahwa tanggung jawab pedagangan (merchant) atau dalam hal ini dapat disebut sebagai pengguna platform disebutkan wajib menyediakan informasi yang lengkap dan benar berkaitan dengan syarat kontrak dan produk barang da atau jasa yang ditawarkan.

Berdasarkan penjelasan di atas terlihatlah dengan jelas kedudukan online shop atau disebut dengan pengguna platform adalah sebagai pihak yang memiliki tanggung jawab atas barang dagangannya, bukan pada penyedia platform (Bukalapak). Batasan-batasan tanggungjawab ini sudah seharusnya dibuat dan dijelaskan agar masyarakat tidak mengalami kesalahan dalam mendudukkan pihak yang semestinya bertanggung jawab atas kerugian yang dialaminya terkait dengan barang yang dibeli secara online melalui platform tertentu.

\section{KESIMPULAN DAN SARAN Kesimpulan}

Setiap orang berhak untuk membuat perjanjian tentang apapun baik yang diatur dalam undang-undang maupun yang tidak ada ketentuannya dalam undang-undang. adanya asas kebebasan berkontrak di atas tidak adanya suatu pembatasan atau hambatan dalam membuat isi perjanjian tersebut asalkan tidak melanggar syarat sahnya suatu perjanjian yang telah diatur di dalam Pasal 1320 KUHPerdata. jual beli online adalah termasuk bagian yang tidak terpisahkan dalam penerapan asas kebebasan berkontrak sesuai yang diatur di dalam Pasal 1338 KUHPerdata. Kedua, perlindungan hukum bagi pembeli yang dirugikan di online shop telah diatur di dalam Undang-Undang Nomor 8 Tahun 1999 tentang Perlindungan Konsumen, Undang-Undang Nomor 19 Tahun 2016 tentang Informasi dan Transaksi Elektronik, serta KUHP.

\section{Saran}

Perjanjian yang dilakukan dengan format elektronik pada dasarnya sudah harus diperjelas melalui undang-undang khusus. Undang-Undang Nomor 19 Tahun 2016 tentang 
Informasi dan Transakso Elektronik belum cukup untuk mengakomodir ketentuan perjanjian yang dimaksud. Kedua, walaupun Surat Edaran Menteri Kominfo Nomor 5 Tahun 2016 Tentang Batasan Dan Tanggung Jawab Penyedia Platform dan Merchant Electronic Commerce sudah ada namun pentingnya peraturan menteri terkait dengan kedudukan antara penyedia platform dan pengguna platform sejauh mana pertanggungjawaban masing-masing pelaku usaha tersebut dalam melakukan kegiatannya masing-masing. 


\section{DAFTAR PUSTAKA}

Ali, Zainuddin. (2009). Metode Penelitian Hukum. Edisi 1 (satu), Cetakan Pertama. Jakarta: Sinar Grafika.

Amiruddin dan Asikin, Zainal. (2013). Pengantar Metode Penelitian Hukum. Edisi Satu, Cetakan Ketujuh. Jakarta: Rajawali Pers.

Ediwarman. (2009). Monograf Metode Penelitian Hukum. Edisi satu. Medan: Genta Publishing.

Ibrahim, Jhonny. (2006). Teori Dan Metedologi Penelitian Hukum Normatif, Jakarta: Pustaka Pelajar.

Ibrahim, Jhonny. (2006). Teori Dan Penelitian Hukum Normatif. Malang: Publishing.

Muhadar. (2006). Viktimisasi Kejahatan Di bidang Pertanahan. LaksBang PRESSindo: Yogyakarta.

Ramadhani, Rahmat. (2019). Eksistensi Hak Komunal Masyarakat Hukum Adat Dalam Pengadaan Tanah untuk Kepentingan Hukum. Jurnal Penelitian Hukum De Jure, Vol. 19, No. 1, 98.

Sanusi, Arsyad, M. (2011). Tebaran Pemikiran Hukum dan Konstitusi. Jakarta: Milestone

Soekamto, Soerjono., \&Mamudji, Sri. (1995). Penelitian Hukum Normatif Suatu Tinjauan Singkat. Jakarta: RajaGrafindo Persada.

Waluyo, Bambang. (1996). Penelitian Hukum Dalam Praktek. Jakarta: Sinar Grafika. 